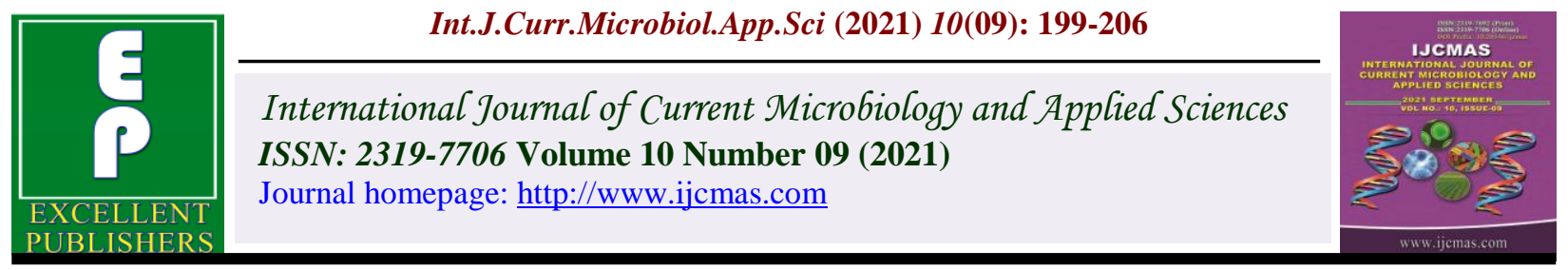

Original Research Article

https://doi.org/10.20546/ijcmas.2021.1009.023

\title{
Impact of Macronutrients and Micronutrients on Soil Health Nutrients Concentration and Uptake by Maize (Zea mays L)
}

\author{
M. L. Bubarai ${ }^{{ }^{*}}$, U. Bapetel ${ }^{2}$ and A. Musa Mala ${ }^{2}$ \\ ${ }^{1}$ Department of Soil Science and Agricultural Chemistry, Samhiggin Bottom University of \\ Agriculture Science and Technology Prayagraj, India \\ ${ }^{2}$ Department of Soil Science, Modibbo Adama University of Science and Technology, \\ Yola, Nigeria \\ *Corresponding author
}

\section{A B S T R A C T}

Keywords

Macro and

micronutrients, soil

health, and nutrients

concentrations

Article Info

Accepted:

12 August 2021

Available Online:

10 September 2021
At the SHUATS Department of Soil Science and Agricultural Chemistry Research Farm, an experiment was conducted with the goal of determining the impact of application of macro and micronutrients, on soil health nutrients concentration and uptake by maize (Zea mays L). The experiment was put up based on this over a two-year period, beginning with the 2017 and 2018 cropping periods. Crbd was used as the experimental technique and it was replicated thrice with the following treatments combinations, NPK @ 50 and $100 \mathrm{kgha}^{-1}$, while for the micronutrients (Boron, Zinc and Copper) three levels of combination were used $0.3,6$ and $9 \mathrm{kgha}^{-1}$. The research project's findings showed all the determinants of soil health like soil reaction organic matter among others are at levels suitable for nutrients actions and plant growth, while plant parameters like maize cob diameter, dry matter, and nutrients concentrations in maize tissues have greatly improved. NPK @ $100 \mathrm{kgha}^{-1}$, Copper, Zinc, and Boron @ $9 \mathrm{kgha}^{-1}$ were the best treatment combinations with the best results. The above combinations of treatments will be suitable for the soils of that location based on the results of these studies.

\section{Introduction}

Macronutrients play a crucial role in plant growth and development. Their roles range from structural components to redox-sensitive agents. In general, applying macronutrients to crops improves production, growth, and quality. Macronutrients were divided into two classes based on their functions: primary macronutrients, such as $\mathrm{N}, \mathrm{P}$, and $\mathrm{K}$, and secondary macronutrients, such as $\mathrm{Ca}, \mathrm{Mg}$, and S. (Morgan and Connolly 2013; Allen and Pilbeam 2007). Micronutrients, also known as trace elements, are minute amounts of 
nutrients that plants require and whose absence might obstruct some physiological aspects of plant growth. Boron, copper zinc, molybdenum, nickel, iron manganese, and chlorine are among them. The blend of micro and macronutrients plays an important part in the plant's life cycle, performing a variety of useful metabolic functions. Nutrients levels of the soils can impact greatly on the status of soils health especially when they are apply in excessive amount.

\section{Materials and Methods}

During the 2017 and 2018 Kharif seasons, an experiment was done at the University of Agriculture, Technology and Science Sam Higginbottom Prayagraj (Allahabad) in Utter Pradesh Soil Science research farm. The area is located at latitudes 25024 '46, 14 'north latitude, 81050', longitude 8100 '49, 91 'east longitude and $98 \mathrm{~m}$ above sea level. The treatments included 0,50 and $100 \mathrm{~kg}$ of nitrogen, phosphorus, and potassium per hectare, as well as $0,3,6$, and $9 \mathrm{~kg}$ of boron, copper, and zinc per hectare. The treatments were replicated three times in a completely randomized method.

\section{Results and Discussion}

Some of the important determinants of soil health are presented in Table 1. It indicated that the soil $\mathrm{pH}$ is 6.7 which is slightly acidic (Brady, 1999). The measurement of soil $\mathrm{pH}$ is a very good phenomenon of indicating how healthy a soil is. According to (Brady, 1996), the optimum range for the growth of most plant is between the range of 5.5 to 7.0. These Soils therefore have a suitable soil reaction for the growth of the experimental crop which is maize. The electrical conductivity (EC) of 0.7 mmhos $/ \mathrm{cm}$ was recorded for the soils. EC is also another important determinant of soil health since it regulate the activities of microorganisms in soils, it also determines nutrient availability to crop and hence crop yield. The EC of the soil of the experimental field is suitable for the growth of crop as it does not fall within the hazardous limit for growth of crop as the value recorded is 0.7 $\mathrm{dSm}^{-1}$ which is far below the hazardous saline level of $4 \mathrm{mmhos} / \mathrm{cm}$ described by Nayak, et al., (2016). The bulk density of the soil $1.22 \mathrm{~g} / \mathrm{c}$ as shown in Table 1 is also suitable for the growth of crop as the value recorded fall within the normal range for root penetration. This finding is in line with Pravin et al., (2013) who outline the range bulk density for sand and clay in his findings to be the same with this result. The value of $2.31 \mathrm{~g} / \mathrm{cm}^{3}$ was recorded for the particle density as shown in Table 1, the result of the particle density of the experimental soil falls within the normal range of soil as describe by Dilip (2015). While the Organic Carbon of 2.6 was recorded and the organic matter obtained is $4.5 \%$. The total nitrogen of the soil is $1.22 \mathrm{~g} / \mathrm{kg}$ while available $\mathrm{P}$ was $20.55 \mathrm{mg} / \mathrm{kg}$

The water holding capacity of the soil recorded was $64 \%$ which indicated that the texture of the soil in general is capable of holding water for the crop to grow under rainfall or irrigation condition.

The organic carbon of the soils recorded was $2.6 \%$ while the organic matter is $4.5 \%$, according to the interpretation of Ameresh et $a l$. , (2016) for soils of India the organic carbon and organic matter content of the soils is described as being in high quantity. These entails that there is so many significant benefits which the crop has benefitted during the period of the trials, among the benefit is the ability to retain the added nutrients and water for the uptake by the plant Organic matter is among the soil factors which improves soil health and increases crop yield as reported by John et al., (2013). The total nitrogen of experiment farm recorded was $1.22 \mathrm{~g} / \mathrm{kg}$ which falls within the low categories 
of nutrients availability as describe by Durai (2014), it therefore means that the soils will response adequately to fertilizer application especially nitrogen.

\section{Effect of Macronutrients (NPK) and micronutrients ( $\mathrm{B}, \mathrm{Cu}$ and $\mathrm{Zn}$ ) on cobs diameter}

The result presented on (Table 2) is showing influence of applying macronutrients (NPK) and the micronutrients $(\mathrm{B}, \mathrm{Zn}$ and $\mathrm{Cu})$ on cob diameter of maize for 2017 and 2018 experimental seasons. In 2017 the values that were recorded ranges from $14.30 \mathrm{~mm}$; $14.20 \mathrm{~mm}$ and $13.70, \mathrm{~mm}$ which were recorded from treatments $100 \mathrm{kgNPK}+6 \mathrm{kgB} \mathrm{ha}^{-1}$; $100 \mathrm{kgNPK}+9 \mathrm{kgB}, \mathrm{Zn}$ and $\mathrm{Cuha}^{-1}$ and the control plot.

The data shows a significant difference among the result for that period while there was also a significant $(\mathrm{P}<0.05)$ interaction between the nutrients. In the second year of the experiments in 2018 cropping period the values recorded were as follows $15.27 \mathrm{~mm}$; $15.17 \mathrm{~mm}$ and $13.00 \mathrm{~mm}$ which was obtained from application of treatments $100 \mathrm{kgNPK}$ $+6 \mathrm{~kg} \mathrm{~B}, \mathrm{Zn}$ and $\mathrm{Cuha}^{-1} ; 100 \mathrm{~kg} \mathrm{NPK}+9 \mathrm{~kg} \mathrm{~B}$, $\mathrm{Zn}$ and $\mathrm{Cuha}^{-1}$ and the control plot. There was also a significant $(\mathrm{P}<0.05)$ interaction between the nutrients.

The pooled mean data for the two years also shows a significant difference between the two years of the study duration (Table 2). The increased in cob diameter can be ascribed to the action of both macro and micro nutrients which significantly contribute to the enhancement of all the growth characters of the maize plant. Similar explanation was credited to Muhammad et al., 2019; and Shrifail et al., 2012), they reported that the yield parameters of maize increases drastically at each level with the addition of various nutrients and some agronomic practices.
Effect of Macronutrients (NPK) and Micronutrients (B ZN, CU) on dry matter of maize (Zea mays L.)

The result presented on Table 4 shows the effect of application of $B$, zinc copper and NPK on dry matter production of maize for the year 2017 and 2018. As the data indicated in the first year of the trial the highest dry matter production of $45.13 \mathrm{~g}$ was recorded with treatments $100 \mathrm{~kg} \mathrm{NPK}+9 \mathrm{KgBha}^{-1}$ this is followed by $39.66 \mathrm{~g}$ which was obtained with treatments $100 \mathrm{~kg} \quad \mathrm{NPK}+6 \mathrm{KgBha}^{-1}$ respectively. The lowest dry matter production $5.11 \mathrm{~g}$ was recorded with control plot, there was a significant difference $(\mathrm{P}<0.05)$ among the treatments in the first year of the trial. In the second year of the experiment 2018 the result recorded also shows a significant difference $(\mathrm{P}<0.05)$ among the treatments use. The maximum dry matter production $47.77 \mathrm{~g}$ was recorded with treatments $100 \mathrm{kgNPK}$ $+6 \mathrm{KgBha}^{-1}$ while the second value of $29.37 \mathrm{~g}$ was obtained will application of treatments $100 \mathrm{~kg} \mathrm{NPK}+9 \mathrm{KgBha}^{-1}$. The lowest value $7.75 \mathrm{~g}$ of dry matter production was recorded with control plot. There was also a significant difference $(\mathrm{P}<0.05)$ among the treatments. Also the pooled mean data between the two years shows a significant difference $(\mathrm{P}<0.05)$ among the treatments.

The outcome of this work as clearly shows the impact of the treatments on the production of dry matter of maize. The result of this research is in agreement with many scholars viz: (Mehmet et al., 2017; Bisnu et al., 2010 and Moniruzzaman et al., 2007). They noted that the application of B and NPK resulted in the production of dry matter of maize which could be due to the action of $B$ which favor the uptake of some nutrients notably phosphorus in the soil, Another factor which may lead to the production of high dry matter could be as a result of one of its function in translocation of starch, sugar and carbohydrate to various 
tissues of the plant. This observation was also view by Balasubramanian et al., (1998) in which they reported that dry matter content of tomato fruit was due to the impact of the application of B and NPK.

\section{Nitrogen concentrations in shoots of maize (Zea mays L.)}

The result presented on Table 5 show the concentration of nitrogen in shoots of maize for the year 2017 trials. As indicated the highest concentrated of nitrogen $3.00 \mathrm{mg} / \mathrm{g}$ was recorded with the application of $100 \mathrm{~kg}$ NPK $+9 \mathrm{kgB}, \mathrm{Zn}$ and $\mathrm{Cu} \mathrm{kg}$ ha- 1 . The second highest concentration of $2.00 \mathrm{mg} \mathrm{g}^{-1}$ was obtained with $100 \mathrm{~kg} \mathrm{NPK}+6 \mathrm{~kg} \mathrm{~B} \mathrm{Zn} \mathrm{and} \mathrm{Cu}$ $\mathrm{ha}^{-1}$. While the lowest concentration of $0.20 \mathrm{mg} / \mathrm{g}$ was recorded with control plots.

The result recorded in that week of the trial shows a significant $(\mathrm{P}<0.05)$ effect of all the treatments. That is the interaction between $\mathrm{B}$ and NPK was significant. Similar observation was noted in the second year of the trial
(2019) in which the highest Nitrogen concentration of $5.00 \mathrm{mgg}^{-1}$ was recorded with treatments $100 \mathrm{~kg}$ NPK $+6 \mathrm{~kg} \mathrm{~B}, \mathrm{Zn}$ and $\mathrm{Cuha}^{-}$ 1 .

While the second value of $3.5 \mathrm{mgg}$ was recorded with treatments $100 \mathrm{~kg} \mathrm{NPK}+9 \mathrm{~kg} \mathrm{~B}$, $\mathrm{Zn}$ and $\mathrm{Cu}, \mathrm{ha}^{-1}$ and the lowest value of $0.10 \mathrm{mgg}^{-1}$ were obtained with control plot. There was a significant difference among the treatments $(\mathrm{P}<0.05)$. Also the pooled mean data for the two years shows a significant $(\mathrm{P}<0.05)$ difference among the treatment.

The concentration of Nitrogen in the shoots of maize crop may be as a result of $\mathrm{B}$ action which causes more nitrogen to be taking up from the soil medium through absorption. Some research work which investigated the action of B in helping nutrients in take from the growing medium reported similar discovery of nutrients concentrations in plant parts (Farshid et al., 2011; and Soomro et al., 2001).

Table.1 Some Important Properties of Soils of the Experimental Farm

\begin{tabular}{|c|c|}
\hline Soil parameters & Result \\
\hline $\mathrm{pH}\left(\mathrm{H}_{2} \mathrm{O}\right)$ & 6.7 \\
\hline $\mathrm{EC}$ mmhos/cm & 0.7 \\
\hline Bulk density $\mathrm{Mg} / \mathrm{m}^{3}$ & 1.22 \\
\hline Particle density $\mathrm{Mg} / \mathrm{m}^{3}$ & 2.31 \\
\hline Pore space $\%$ & 51.41 \\
\hline Water holding capacity $(\%)$ & 64 \\
\hline Organic carbon (\%) & 2.6 \\
\hline Organic matter (\%) & 4.5 \\
\hline Sand & 66.13 \\
\hline Silt & 20.12 \\
\hline Clay & 12.6 \\
\hline Textural Class & Sandy loam \\
\hline
\end{tabular}


Table.2 Effect of Macronutrients (NPK) and micronutrients (B, $\mathrm{Cu}$ and $\mathrm{Zn}$ ) on cobs diameter

\begin{tabular}{|c|c|c|c|c|c|c|c|c|c|c|c|c|}
\hline \multirow[t]{3}{*}{$\begin{array}{l}\text { Treatments } \\
\text { Levels }\end{array}$} & \multirow{2}{*}{\multicolumn{3}{|c|}{ I avels of NPK }} & \multirow[t]{3}{*}{$\begin{array}{c}\text { Mean } \\
\text { B }\end{array}$} & \multicolumn{3}{|c|}{2018} & $\begin{array}{c}\text { Mean } \\
\text { B }\end{array}$ & \multicolumn{2}{|c|}{ Pooled } & & \multirow[t]{3}{*}{$\begin{array}{c}\text { Mean } \\
\text { B }\end{array}$} \\
\hline & & & & & \multicolumn{3}{|c|}{ Levels of NPK } & & \multicolumn{3}{|c|}{ Levels of NPK } & \\
\hline & $\mathrm{X}_{0}$ & $\begin{array}{l}\mathrm{X}_{2}: 50 \\
\mathrm{Kg} / \mathrm{ha}\end{array}$ & $\begin{array}{l}\mathrm{X}_{3} 100 \\
\mathrm{Kg} / \mathrm{ha}\end{array}$ & & $\mathrm{X}_{0}$ & $\begin{array}{l}\mathrm{X}_{2}: 50 \\
\mathrm{Kg} / \mathrm{ha}\end{array}$ & $\begin{array}{l}\mathrm{X}_{3} 100 \\
\mathrm{Kg} / \mathrm{ha}\end{array}$ & & $\mathrm{X}_{0}$ & $\begin{array}{l}\mathrm{X}_{2}: 50 \\
\mathrm{Kg} / \mathrm{ha}\end{array}$ & $\begin{array}{l}\mathrm{X}_{3} 100 \\
\mathrm{Kg} / \mathrm{ha}\end{array}$ & \\
\hline B $_{\text {0-Control }}$ & 15.50 & 13.56 & 14.16 & 14.41 & 16.47 & 14.53 & 14.92 & 15.31 & 15.99 & 14.05 & 14.54 & 14.86 \\
\hline $\mathbf{B}_{1-3 \mathrm{k} g / \mathrm{ha}}$ & 15.00 & 13.76 & 14.06 & 14.27 & 15.79 & 14.70 & 15.03 & 15.17 & 15.40 & 14.23 & 14.55 & 14.72 \\
\hline $\mathbf{B}_{2(6 \mathrm{~kg} / \mathrm{ha})}$ & 14.03 & 13.96 & 14.30 & 14.10 & 14.79 & 14.87 & 15.27 & 14.98 & 14.41 & 14.42 & 14.79 & 14.54 \\
\hline $\mathbf{B}_{3(9 \mathrm{~kg} / \mathrm{ha})}$ & 13.70 & 13.90 & 14.20 & 13.93 & 14.67 & 14.85 & 15.17 & 14.90 & 14.19 & 14.38 & 14.69 & 14.42 \\
\hline \multirow[t]{2}{*}{ Mean (X) } & 14.56 & 13.80 & 14.18 & & 15.43 & 14.74 & 15.10 & & 14.99 & 14.27 & 14.64 & \\
\hline & & F test & $\begin{array}{l}\text { S.Ed. } \\
( \pm)\end{array}$ & $\begin{array}{l}\text { C.D at } \\
5 \%\end{array}$ & & F test & $\begin{array}{l}\text { S.Ed. } \\
( \pm)\end{array}$ & $\begin{array}{l}\text { C.D at } \\
5 \%\end{array}$ & F test & $\begin{array}{l}\text { S.Ed. } \\
( \pm)\end{array}$ & $\begin{array}{l}\text { C.D at } \\
5 \%\end{array}$ & \\
\hline B1 B2 B3 & & S & 0.167 & 0.340 & & S & 0.141 & 0.289 & $S$ & 0.154 & 0.313 & \\
\hline NPK $(X)$ & & S & 0.144 & 0.294 & & S & 0.122 & 0.250 & S & 0.133 & 0.271 & \\
\hline Inter B x X & & $\mathrm{S}$ & 0.289 & 0.589 & & $S$ & 0.245 & 0.500 & $S$ & 0.266 & 0.543 & \\
\hline
\end{tabular}

B1, B2 and B3 = B, Zinc and Copper

Table.3 Effect of Macronutrients (NPK) and micronutrients (B, $\mathrm{Cu}$ and $\mathrm{Zn}$ ) on dry matter

\begin{tabular}{|c|c|c|c|c|c|c|c|c|c|c|c|c|}
\hline \multirow{3}{*}{$\begin{array}{l}\text { Treatments } \\
\text { Levels }\end{array}$} & \multicolumn{3}{|c|}{2017} & \multirow{3}{*}{$\begin{array}{c}\text { Mean } \\
\text { B }\end{array}$} & \multicolumn{3}{|c|}{2018} & \multirow{3}{*}{$\begin{array}{c}\text { Mean } \\
\text { B }\end{array}$} & \multicolumn{2}{|c|}{ Pooled } & & \multirow{2}{*}{$\begin{array}{c}\text { Mean } \\
\text { B }\end{array}$} \\
\hline & \multicolumn{3}{|c|}{ Levels of NPK } & & \multicolumn{3}{|c|}{ Levels of NPK } & & \multicolumn{3}{|c|}{ Levels of NPK } & \\
\hline & $\mathrm{X}_{0}$ & $\begin{array}{l}\mathrm{X}_{2}: 50 \\
\mathrm{Kg} / \mathrm{ha}\end{array}$ & $\begin{array}{l}\mathrm{X}_{3} 100 \\
\mathrm{Kg} / \mathrm{ha}\end{array}$ & & $\mathrm{X}_{0}$ & $\begin{array}{l}\mathrm{X}_{2}: 50 \\
\mathrm{Kg} / \mathrm{ha}\end{array}$ & $\begin{array}{l}\mathrm{X}_{3} 100 \\
\mathrm{Kg} / \mathrm{ha}\end{array}$ & & $\mathrm{X}_{0}$ & $\begin{array}{l}\mathrm{X}_{2:} 50 \\
\mathrm{Kg} / \mathrm{ha}\end{array}$ & $\begin{array}{l}\mathrm{X}_{3} 100 \\
\mathrm{Kg} / \mathrm{ha}\end{array}$ & \\
\hline B $_{\text {0-Control }}$ & 5.11 & 16.00 & 29.48 & 16.86 & 7.75 & 23.70 & 29.90 & 20.45 & 6.43 & 19.85 & 29.69 & 18.66 \\
\hline $\mathbf{B}_{1-3 \mathrm{~kg} / \mathrm{ha}}$ & 13.42 & 14.64 & 31.18 & 19.75 & 20.06 & 22.47 & 35.69 & 26.07 & 16.74 & 18.55 & 33.44 & 22.91 \\
\hline $\mathbf{B}_{2(6 \mathrm{~kg} / \mathrm{ha})}$ & 12.88 & 11.20 & 39.66 & 21.25 & 20.21 & 33.43 & 47.77 & 33.80 & 16.55 & 22.32 & 43.71 & 27.53 \\
\hline $\mathbf{B}_{3(9 \mathrm{~kg} / \mathrm{ha})}$ & 12.85 & 19.90 & 45.13 & 25.96 & 23.53 & 36.90 & 29.37 & 29.93 & 18.19 & 28.40 & 37.25 & 27.95 \\
\hline Mean (X) & & & & & 17.89 & 29.13 & 35.68 & & 14.48 & 22.28 & 36.02 & \\
\hline & & F test & $\begin{array}{l}\text { S.Ed. } \\
( \pm)\end{array}$ & $\begin{array}{c}\text { C.D at } \\
5 \%\end{array}$ & & $\mathrm{~F}$ test & $\begin{array}{l}\text { S.Ed. } \\
( \pm)\end{array}$ & $\begin{array}{c}\text { C.D at } \\
5 \%\end{array}$ & F test & $\begin{array}{l}\text { S.Ed. } \\
( \pm)\end{array}$ & $\begin{array}{l}\text { C.D at } \\
5 \%\end{array}$ & \\
\hline B1 B2 B3 & & $\mathrm{S}$ & 2.300 & 4.692 & & $\mathrm{~S}$ & 2.517 & 5.139 & $\mathrm{~S}$ & 1.925 & 3.931 & \\
\hline NPK (X) & & S & 1.992 & 4.064 & & S & 2.179 & 4.450 & $S$ & 1.667 & 3.404 & \\
\hline Inter B x X & & S & 3.984 & 8.127 & & S & 4.359 & 8901 & $\mathrm{~S}$ & 3.334 & 6.809 & \\
\hline
\end{tabular}

Table.4 Nitrogen Concentrations in Plant Tissues

\begin{tabular}{|c|c|c|c|c|c|c|c|c|c|c|c|c|}
\hline \multirow[t]{3}{*}{$\begin{array}{c}\text { Treatments } \\
\text { Levels }\end{array}$} & \multicolumn{3}{|c|}{2017} & \multirow[t]{3}{*}{$\begin{array}{c}\text { Mean } \\
\text { B }\end{array}$} & \multicolumn{3}{|c|}{2018} & $\begin{array}{c}\text { Mean } \\
\text { B }\end{array}$ & \multicolumn{2}{|c|}{ Pooled } & & \multirow[t]{3}{*}{$\begin{array}{c}\text { Mean } \\
\text { B }\end{array}$} \\
\hline & \multicolumn{3}{|c|}{ Levels of NPK } & & \multicolumn{3}{|c|}{ Levels of NPK } & & \multicolumn{3}{|c|}{ Levels of NPK } & \\
\hline & $\mathrm{X}_{0}$ & $\begin{array}{l}\mathrm{X}_{2}: 50 \\
\mathrm{Kg} / \mathrm{ha}\end{array}$ & $\begin{array}{l}\mathrm{X}_{3} 100 \\
\mathrm{Kg} / \mathrm{ha}\end{array}$ & & $\mathrm{X}_{0}$ & $\begin{array}{l}\mathrm{X}_{2}: 50 \\
\mathrm{Kg} / \mathrm{ha}\end{array}$ & $\begin{array}{l}\mathrm{X}_{3} 100 \\
\mathrm{Kg} / \mathrm{ha}\end{array}$ & & $\mathrm{X}_{0}$ & $\begin{array}{l}\mathrm{X}_{2} .50 \\
\mathrm{Kg} / \mathrm{ha}\end{array}$ & $\begin{array}{l}\mathrm{X}_{3} 100 \\
\mathrm{Kg} / \mathrm{ha}\end{array}$ & \\
\hline $\mathbf{B}_{0 \text {-Control }}$ & 0.10 & 1.25 & 1.40 & 0.95 & 0.10 & 2.00 & 4.00 & 2.07 & 0.10 & 1.63 & 2.70 & 1.51 \\
\hline$B_{1-3 k g / h a}$ & 0.20 & 1.20 & 1.50 & 0.93 & 0.20 & 3.00 & 4.00 & 2.37 & 0.20 & 2.10 & 2.75 & 1.65 \\
\hline $\mathbf{B}_{2(6 \mathrm{~kg} / \mathrm{ha})}$ & 1.00 & 1.25 & 2.00 & 1.42 & 0.30 & 4.00 & 3.00 & 3.10 & 0.65 & 2.63 & 3.50 & 2.26 \\
\hline $\mathbf{B}_{3(9 \mathrm{~kg} / \mathrm{ha})}$ & 1.25 & 1.25 & 3.00 & 1.50 & 0.50 & 4.00 & 5.00 & 3.17 & 0.88 & 2.63 & 3.50 & 2.33 \\
\hline Mean $(X)$ & 0.64 & 1.24 & 1.73 & & 0.28 & 3.25 & 4.50 & & 0.46 & 2.24 & 3.11 & \\
\hline & & F-test & $\begin{array}{l}\text { S. Ed. } \\
( \pm)\end{array}$ & $\begin{array}{l}\text { C.D. at } \\
5 \%\end{array}$ & $\begin{array}{l}\text { F- } \\
\text { test }\end{array}$ & $\begin{array}{l}\text { S. Ed. } \\
( \pm)\end{array}$ & $\begin{array}{l}\text { C.D. at } \\
5 \%\end{array}$ & & $\begin{array}{l}\text { F- } \\
\text { test }\end{array}$ & $\begin{array}{c}\text { S. Ed. } \\
( \pm)\end{array}$ & $\begin{array}{l}\text { C.D. at } \\
5 \%\end{array}$ & \\
\hline NPK (X) & & $S$ & 0.004 & 0.008 & $\mathrm{~S}$ & 0.004 & 0.009 & & $\mathrm{~S}$ & 0.004 & 0.009 & \\
\hline
\end{tabular}

$\mathrm{B} 1, \mathrm{~B} 2$ and B3 = B, Zinc and Copper 
Table.5 Concentration of B in Shoots of Maize (Zea mays L.)

\begin{tabular}{|c|c|c|c|c|c|c|c|c|c|c|c|c|}
\hline \multirow[t]{3}{*}{$\begin{array}{l}\text { Treatments } \\
\text { Levels }\end{array}$} & \multicolumn{3}{|c|}{2017} & \multirow[t]{3}{*}{$\begin{array}{c}\text { Mean } \\
\text { B }\end{array}$} & \multicolumn{3}{|c|}{2018} & $\begin{array}{c}\text { Mean } \\
\text { B }\end{array}$ & \multicolumn{2}{|c|}{ Pooled } & & \multirow[t]{3}{*}{$\begin{array}{c}\text { Mean } \\
\text { B }\end{array}$} \\
\hline & \multicolumn{3}{|c|}{ Levels of NPK } & & \multicolumn{3}{|c|}{ Levels of NPK } & & \multicolumn{3}{|c|}{ Levels of NPK } & \\
\hline & $\mathrm{X}_{0}$ & $\begin{array}{l}\mathrm{X}_{2}: 50 \\
\mathrm{Kg} / \mathrm{ha}\end{array}$ & $\begin{array}{l}\mathrm{X}_{3} 100 \\
\mathrm{Kg} / \mathrm{ha}\end{array}$ & & $\mathrm{X}_{0}$ & $\begin{array}{l}\mathrm{X}_{2}: 50 \\
\mathrm{Kg} / \mathrm{ha}\end{array}$ & $\begin{array}{l}\mathrm{X}_{3} 100 \\
\mathrm{Kg} / \mathrm{ha}\end{array}$ & & $\mathrm{X}_{0}$ & $\begin{array}{l}\mathrm{X}_{2: 50} \\
\mathrm{Kg} / \mathrm{ha}\end{array}$ & $\begin{array}{l}\mathrm{X}_{3} 100 \\
\mathrm{Kg} / \mathrm{ha}\end{array}$ & \\
\hline $\mathbf{B}_{0 \text {-Control }}$ & 0.100 & 0.110 & 1.000 & 0.403 & 0.100 & 0.110 & 1.200 & 0.470 & 0.100 & 0.110 & 1.100 & 0.437 \\
\hline $\mathbf{B}_{1-3 \mathrm{k} g / \mathrm{ha}}$ & 0.100 & 0.130 & 1.000 & 0.410 & 0.100 & 0.130 & 1.220 & 0.483 & 0.100 & 0.130 & 1.110 & 0.447 \\
\hline$B_{2(6 \mathrm{~kg} / \mathrm{ha})}$ & 0.150 & 0.190 & 1.100 & 0.447 & 0.150 & 0.190 & 3.000 & 1.113 & 0.150 & 0.190 & 2.000 & 0.780 \\
\hline $\mathbf{B}_{3(9 \mathrm{~kg} / \mathrm{ha})}$ & 0.600 & 0.180 & 2.000 & 0.440 & 0.140 & 0.180 & 2.000 & 0.927 & 0.370 & 0.180 & 1.500 & 0.683 \\
\hline Mean (X) & 0.238 & 0.153 & 1.000 & & 0.123 & 0.153 & 1.000 & & 0.180 & 0.153 & 1.428 & \\
\hline & & F test & $\begin{array}{l}\text { S.Ed. } \\
( \pm)\end{array}$ & $\begin{array}{c}\text { C.D at } \\
5 \%\end{array}$ & & F test & $\begin{array}{l}\text { S.Ed. } \\
( \pm)\end{array}$ & $\begin{array}{c}\text { C.D at } \\
5 \%\end{array}$ & F test & $\begin{array}{l}\text { S.Ed. } \\
( \pm)\end{array}$ & $\begin{array}{l}\text { C.D at } \\
5 \%\end{array}$ & \\
\hline NPK (X) & & $\mathrm{S}$ & 0.012 & 0.015 & & $\mathrm{~S}$ & 0.008 & 0.025 & $\mathrm{~S}$ & 0.009 & 0.019 & \\
\hline Inter B x X & & $S$ & 0.025 & 0.031 & & $S$ & 0.015 & 0.050 & $S$ & 0.018 & 0.037 & \\
\hline
\end{tabular}

B1, B2 and B3 = B, Zinc and Copper

Concentration of Boron in shoots of maize (Zea mays L.)

The concentration of Boron (B) in maize shoots for the year 2017 and 2018 experimental season as shown in Table 6 indicated that the highest $\mathrm{B}$ concentration of $2.00 \mathrm{mg} / \mathrm{g}$ in 2017 was registered with the application of treatments $100 \mathrm{kgNPK}+9 \mathrm{~kg}, \mathrm{~B}$, $\mathrm{Zn}$ and $\mathrm{Cu}, \mathrm{ha}^{-1}$ this is closely followed by $1.100 \mathrm{mg} / \mathrm{g}$ which was registered with treatments $100 \mathrm{kgNPK}+6 \mathrm{~kg}, \mathrm{~B}, \mathrm{Zn}$ and $\mathrm{Cu}$, ha ${ }^{-}$ 1. As shown on the table there was a significant difference $(\mathrm{P}<0.05)$ among the treatments used and also there was a significant $(\mathrm{P}<0.05)$ interaction effect with the treatments. Lowest value of 0.100 was recorded with control plot. The result in the subsequent year of 2018 registered a significant different among the treatments with the highest value of $3.00 \mathrm{mg} / \mathrm{g}$ been registered with treatments $100 \mathrm{kgNPK}+6 \mathrm{kgB}$, $\mathrm{Zn}$ and $\mathrm{Cuha}^{-1}$, this followed by $2.00 \mathrm{mb} / \mathrm{g}$ which was obtained with treatments $100 \mathrm{~kg}$ $\mathrm{NPK}+9 \mathrm{~kg}, \mathrm{~B}, \mathrm{Zn}$ and $\mathrm{Cu} \mathrm{ha}^{-1}$.

The lowest B concentration $0.100 \mathrm{mg} / \mathrm{g}$ was obtained in control plot. Here also the result indicated a significant difference $(\mathrm{P}<0.05)$ among the treatments, there was also a significant interaction $(\mathrm{P}<0.05)$ effect between the treatments. The pooled mean data of the result also indicated a significant $(\mathrm{P}<0.05)$ difference of the mean result for the two years of the study period.

Boron can accumulate in shoots of corn as a result of steady application of the nutrients in the soil which leads to uptake by the crop and gradually leading to accumulation of B.

In fact this observation was also noted earlier by Serzer, (2014) who concluded by saying that uptake of a nutrients by a crop depends on its availability in the soil and this will gradually leads to its absorption by the crop and hence its accumulation. Farshid (2011) also has another opinion on the accumulation of nutrient in plant tissues where he stated that some elements are capable of increasing the accumulation of other elements in plants tissues. Base on this observation it is possible that this reasons may play a role in the accumulation of B in maize shoot

A field experiment was conducted at the research farm of the department of soil science and agricultural chemistry Sam Higgins Bottom University of Agriculture Science and Technology Prayagraj for two consecutive 
growing seasons (2017 and 2018) to investigate the impact of macronutrients $(\mathrm{NPK})$ and micronutrients $(\mathrm{B}, \mathrm{Zn}$, and $\mathrm{Cu})$ on soil health nutrients concentration and uptake by maize. Three replications of three levels of $\mathrm{B}, \mathrm{Zn}$, and $\mathrm{Cu}(0,3,6$, and $9 \mathrm{mg} \mathrm{kg}-1 \mathrm{~B}, \mathrm{Cu}$, and $\mathrm{Zn})$ and three levels of NPK $(0,50$, and $100 \mathrm{k} \mathrm{kgha}^{-1}$ ) were reproduced three times in a completely randomised design experiment. Before starting the experiments, soil samples were analysed on a regular basis. The plant metrics measured were maize cob diameter, dry matter, and nutrient concentrations in maize tissues, all of which improved dramatically after the treatments were applied. The combined application of NPK @ 100kgha1, Copper, Zinc, and Boron @ 9kgha-1 yielded promising results. The treatment of both macronutrients (NPK) and micronutrients (Boron, Zinc, Copper) together has a considerable impact on maize growth indices and nutrient concentrations in maize tissue. On the growth response of maize plants, there were significant differences in treatment effects. The data clearly show that the physical and chemical parameters of the soil in the experimental farms, in terms of soil health, were at levels that are optimal for nutrient delivery for plant development and microbial activity to thrive. This demonstrated that they help to regulate the flow of nutrients, water, and root penetration, resulting in a very healthy soil.

\section{References}

Amresh, C., Mahesh, C. Meena, C., M. Parihar and Abir, D., (2016) Effect of Long-Term Conservation Agriculture on Soil Organic Carbon and Dehydrogenase Activity under MaizeBased Cropping Systems Int.J.Curr.Microbiol.App.Sci 6(10): 437-444.

Allen, V., Baker, D and Pilbean J. (2007). Hand book of plant nutrition CRC press ISBN 978-8-8247-59049

Retrieved 17August 2010

Bishnu, H., Jiban, S., and Bandhu, R. B.(2010). Effect of micronutrients on growth band productivity of Maize in Acidic Soil. International Journal of Applied and Basic Sciences 8-11.

Balasubramaniam, P., A. K. Mani, P. Duraisamy and Kandaswami $\mathrm{M}$. (1998). Effect of organic and inorganic nutrients on the yield and uptake of tomato. South Indian Hort.46(3-6): 143-147.

Brady, N. C. and Weil, R. R. (1999). The Nature and Properties of Soils.12th Edition, Prentice Hall Publishers, London, 1-9, 453-536, 727, 739-740.

Dilip, K. D.(2015). Introductory Soil Science, Kalyani Publishers, New Delhi, ISBN978-93-272-5754-0; pp 45.

Durai, M. V.(2014) A Hand Book of Soil Plant- Water- Fertilizer and Manure Analysis New India Publishing Agency New Delhi p8.

Farshid. A.(2011). The effect of B and $\mathrm{Zn}$ application on concentration and uptake of Nitrogen Phosphorus and Potassium in corn grain, International Journal of Science and Technology,(4) 0974- 6846

John, L. H., Samuel, L. T. Werner, L., and James, D. L.,(2013) Soil Fertility and Fertilzers An in Introduction to Nutrients Management Pearson India Education Services Pvt. Ltd p11.

Muhammad, Z., Muhammad, Y., Tanveer A. Muhammad, N., Adam M., and Yasir, H.(2019). For application of micronutrients enhances crop stand, yield and the biofortification essential for human health of different wheat Cultivars Journal of Integrative Agriculture 18 (6): 1369-1378.

Mehmet, R. K., Metin, T., Ayhan, H. Tüfenkçi,, M. Ş., and Aydin, A. (2017) Interactive Effects of $\mathrm{B}$ and Humic 
Acid on the Growth and Nutrient Status of Maize Plant (Zea mays L.) International Journal of Plant and Soil Science 19(2): 1-9, $\quad$ Article no.IJPSS.36430 ISSN: 2320-7035.

Morgan, J. B. and Connolly, E. L. (2013) Plant-Soil interactions nutrients uptake. Nature education knowledge $4(8) 2$.

Moniruzzaman, M., Rahman, S. M. L., Kibria, M. G., Rahman, M. A. and Hossain, M. M. (2007). Effect of B and Nitrogen on Yield and Hollow stem of Broccoli.J.Soil.Nature.1(3): 24-29

Nayak, A. K., Bhattacharyya, P., Shahid, M., Tripathi, R., Lal, B., Gautam, P., Mohanty, S., Kumar, A., and Chatterjee, D. (2016). Modern Techniques in Soil and Plant Analysis. Kalyani Publishers, New Delhi, 110002; ISBN: 978-93-272-7059-4; pp 272.

Pravin, R. C., Dodha, V. A., Vidya, D. A., Manab, C., and Saroj, M. (2013)Soil
Bulk Density as related to Soil Texture, Organic Matter Content and available total Nutrients of Coimbatore Soil International Journal of Scientific and Research Publications, Volume (3): I2, 2250-3153

Serzer Sahim (2014) Effect of boron fertilizer application on the growth and boron uptake of maize (Zea mays L.) under the different soils. Journal. Food Agric. Environ. 12(2): 1323- 1327

Sharifai, A. I., Mahmud, M., Tanimu, B and Abubakar, I. U.(2012) Yield and yield components of extra early maize (Zea mzys L.) as influenced by intra-row spacing, nitrogen and poultry manure, Bayero Journal of pure and applied Sciences 5(1): 133-122

Soomro, Z. H. Baloch, P. A., and Gandhai, A. W., (2011) Comparative effect of Foliar and soil applied B on growth and fodder yield of maize $P a k$ journal.Agric Eng;Vet Sci,77(1)18-26

\section{How to cite this article:}

Bubarai, M. L., U. Bapetel and Musa Mala, A. 2021. Impact of Macronutrients and Micronutrients on Soil Health Nutrients Concentration and Uptake by Maize (Zea mays L). Int.J.Curr.Microbiol.App.Sci. 10(09): 199-206. doi: https://doi.org/10.20546/ijcmas.2021.1009.023 